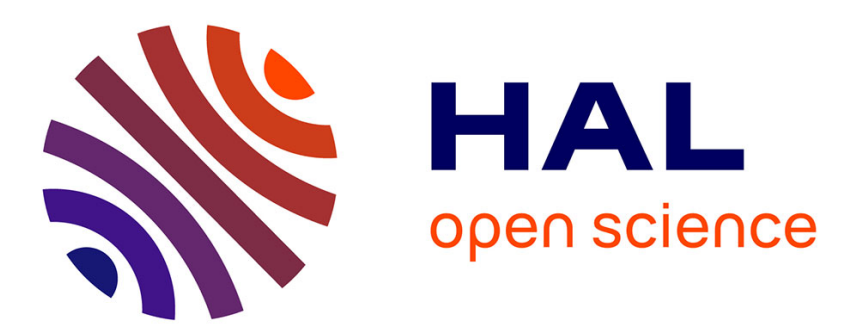

\title{
Visible-Light-Mediated Access to Phosphate Esters
} Alya Inial, Fabrice Morlet-Savary, Jacques Lalevée, Annie-Claude Gaumont, Sami Lakhdar

\section{To cite this version:}

Alya Inial, Fabrice Morlet-Savary, Jacques Lalevée, Annie-Claude Gaumont, Sami Lakhdar. VisibleLight-Mediated Access to Phosphate Esters. Organic Letters, 2020, 22 (11), pp.4404-4407. 10.1021/acs.orglett.0c01409 . hal-03011254

\section{HAL Id: hal-03011254 https://hal.science/hal-03011254}

Submitted on 8 Dec 2020

HAL is a multi-disciplinary open access archive for the deposit and dissemination of scientific research documents, whether they are published or not. The documents may come from teaching and research institutions in France or abroad, or from public or private research centers.
L'archive ouverte pluridisciplinaire HAL, est destinée au dépôt et à la diffusion de documents scientifiques de niveau recherche, publiés ou non, émanant des établissements d'enseignement et de recherche français ou étrangers, des laboratoires publics ou privés. 


\title{
Visible Light-Mediated Access to Phosphate Esters
}

\author{
Alya Inial, ${ }^{\dagger}$ Fabrice Morlet-Savary, ${ }^{\ddagger}$ Jacques Lalevée, ${ }^{\ddagger}$ Annie-Claude Gaumont, ${ }^{\dagger}$ and \\ Sami Lakhdart\&*
}

† Normandie Univ., LCMT, ENSICAEN, UNICAEN, CNRS, 6, Boulevard Maréchal Juin, Caen 14000

France

‡ Université de Haute-Alsace, CNRS, IS2M UMR 7361, F-68100 Mulhouse, France

$\S$ Université Paul Sabatier, Laboratoire Hétérochimie Fondamentale et Appliquée (LHFA, UMR 5069), 118 Route de Narbonne, 31062, Toulouse Cedex 09, France<smiles></smiles><smiles>[R]OP([R])(=O)O</smiles>

OR

$>20$ examples Mechanistic studies

ABSTRACT: we report herein a practically simple visible-light photocatalytic approach for the synthesis of a large varie-ty of phosphate esters through the combination of $\mathrm{N}$-alkoxypyridinium salts and phosphites under mild conditions. The scope of the reaction is broad and was successfully applied to the synthesis of biologically relevant structures. Quantum yield measurement, as well as EPR experiments, allowed the suggestion of a reasonable reaction mechanism.

Phosphate esters are useful structural scaffolds that besides their frequent use in organic synthesis and catalysis are part of natural molecules such as carbohydrates, steroids, nucleic acids and coenzymes. They are furthermore essential in the biochemical regulation of protein-protein interactions and the ATP-based energy conversion in living organisms. ${ }^{1}$ It is not surprising, therefore, that synthesis of those molecules has been and still is the subject of intensive investigations both in academia and industry. Traditionally, access to phosphate esters can be achieved through nucleophilic attack at phosphorus by treatment of alcohols with phosphorus halides. ${ }^{2}$ However, because of the moisture sensitivity and toxicity of the latter, efforts in providing synthetic alternatives to this method are relevant. In this context, Prabhu and colleagues reported an elegant phosphorylation of alcohols using molecular iodine as a catalyst and $\mathrm{H}_{2} \mathrm{O}_{2}$ as an oxidant (Scheme 1, eq. (1)). ${ }^{3}$ The proposed mechanism postulates the catalytic generation of the highly electrophilic phosphoryl iodide that reacts with an alcohol to give the desired phosphate ester. Although efficient, the stoichiometric use of a $\mathrm{H}_{2} \mathrm{O}_{2}$ remains a limitation of this methodology due to its incompatibility with many group functionalities. Importantly, a sustainable approach for the synthesis of phosphinates has been accomplished electrochemically by reaction of various secondary phosphine oxides with alcohols (Scheme 1, eq. (2)). ${ }^{4}$ However, only a single phosphate ester has been synthesized by this approach in a rather moderate yield (30\%). Another route to access phosphate esters consists of the addition of alkoxy radicals to phosphites that typically are rapidly deoxygenated to generate alkyl radicals and phosphate. This approach has for instance been applied by Barton in the photochemical synthesis of steroid-based phosphate esters. ${ }^{5}$ However, this approach has not seen a large application in synthesis despite detailed physical organic investigations of this reactions provided by Bentrude et al. ${ }^{6}$ This might be attributed to a lack of methods enabling generation of alkoxy radicals under mild conditions.

Scheme 1. (A) Reported Approaches for the Synthesis of Ester Phosphates. (B) Current work. 


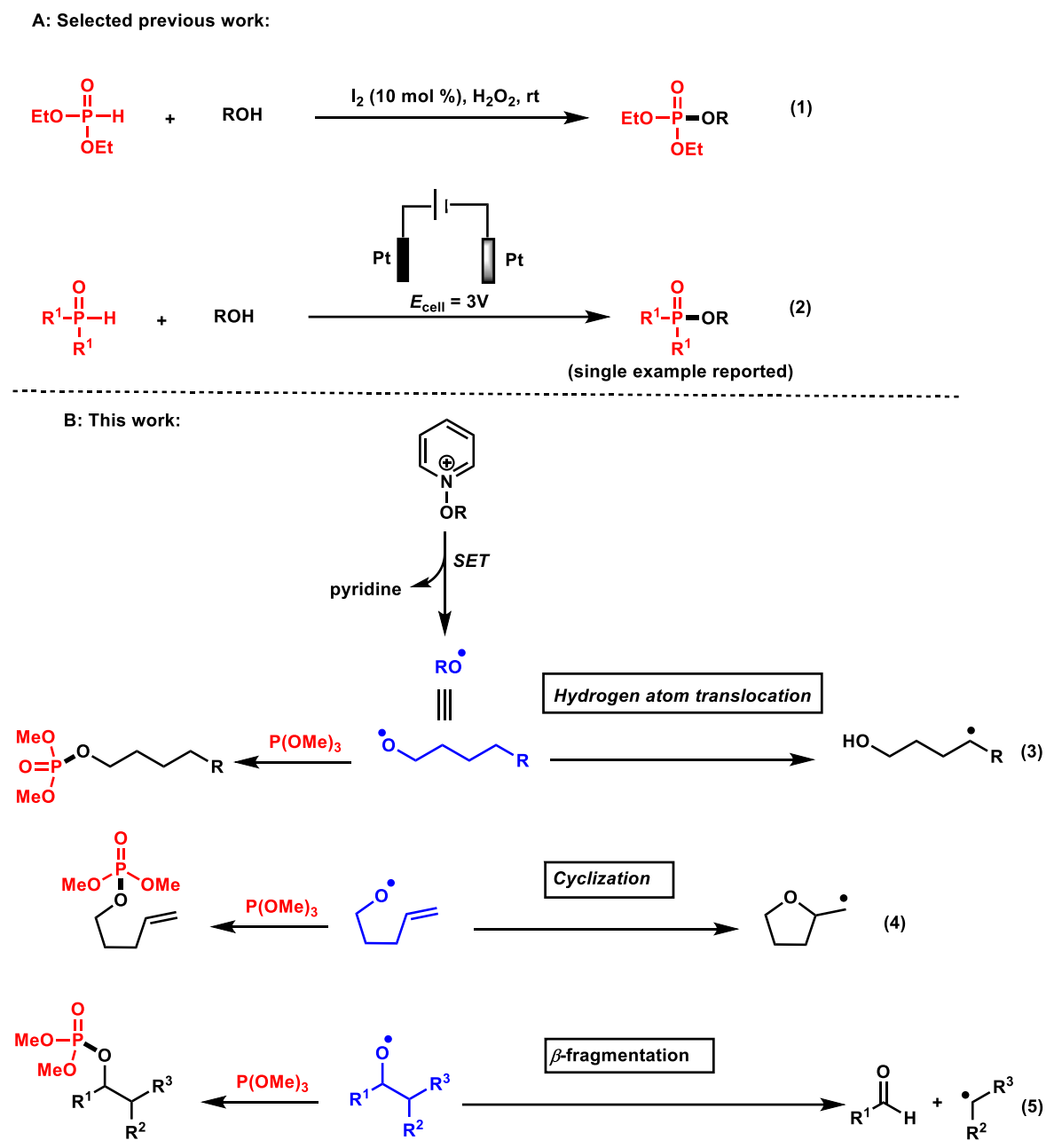

Inspired from these seminal studies and based on the remarkable development of photoredox catalysis as an efficient approach to generate various radical species under mild conditions, ${ }^{7}$ we postulated that synthesis of phosphate esters can be achieved photocatalytically.

Design plan: To this end, we focused on the use of $N$-alkoxypyridinium ions, which have been shown to be privileged precursors for the generation of alkoxy radicals. ${ }^{8}$ Because the addition of those radicals to phosphites are well-known to be irreversible and diffused-controlled $\left(>10^{9} \mathrm{M}^{-1} \mathrm{~s}^{-1}\right),{ }^{6}$ possible alkoxy fragmentations (eq. (35)), ${ }^{9}$ and possible Minisci reaction of generated carbon radicals with the pyridinium salts can be encountered. ${ }^{10}$

Because $(\mathrm{MeO})_{3} \mathrm{P}(\mathbf{1 a})$ is known to be a very reactive and selective trap for the allyloxy radical, ${ }^{11}$ we started our investigation by testing its reactivity with the pyridinium (2a) under photocatalytic conditions. Pyridinium ions were prepared in one step by reaction of pyridine- $N$-oxide with the alkyltosylates, following a protocol reported by Hong. ${ }^{10}$

Table 1. Optimization of the Photocatalytic Reaction of Trimethylphosphite 1 a with the $N$-alkoxypyridinium $2 a^{a}$

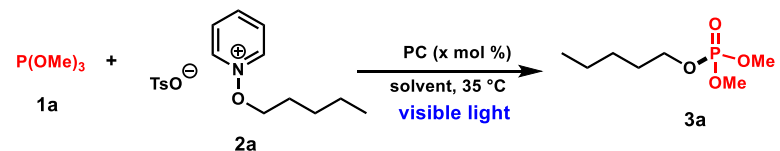

\begin{tabular}{|ccccc|} 
entry $^{a}$ & $\begin{array}{c}\text { Photocatalyst } \\
(\text { PC) }\end{array}$ & $\begin{array}{c}\text { catalyst } \\
\text { loading (\%) }\end{array}$ & solvent & $\begin{array}{c}\text { 3a, yield } \\
{[\%]^{b}}\end{array}$ \\
\hline 1 & Ru(bpy) & 5 & MeCN & 65 \\
2 & Eosin Y & 5 & MeCN & 67 \\
3 & Rose Bengal & 5 & MeCN & 63 \\
4 & fac-Ir(ppy) 3 & 5 & MeCN & 82 \\
\hline
\end{tabular}




\begin{tabular}{|c|c|c|c|c|}
\hline 5 & - & - & $\mathrm{MeCN}$ & traces \\
\hline 6 & $f a c-\operatorname{Ir}(\mathrm{ppy}){ }_{3}{ }^{c}$ & 5 & $\mathrm{MeCN}$ & 72 \\
\hline 7 & $f a c-\operatorname{Ir}(\mathrm{ppy}) \mathrm{3}^{d}$ & 5 & $\mathrm{MeCN}$ & 80 \\
\hline 8 & fac-Ir(ppy) $)_{3}$ & 2 & $\mathrm{MeCN}$ & 81 \\
\hline 9 & $f a c-\operatorname{Ir}(\mathrm{ppy})_{3}$ & 2 & EtOAc & 78 \\
\hline 10 & $f a c-\operatorname{Ir}(\mathrm{ppy})_{3}$ & 2 & $\mathrm{CH}_{2} \mathrm{Cl}_{2}$ & 77 \\
\hline 11 & $f a c-\operatorname{Ir}(\mathrm{ppy})_{3}$ & 2 & DMF & 47 \\
\hline 12 & $f a c-\operatorname{Ir}(\mathrm{ppy})_{3}$ & 2 & $\mathrm{MeOH}$ & 75 \\
\hline 13 & $f a c-\operatorname{Ir}(\mathrm{ppy})_{3}$ & 2 & $\begin{array}{l}\text { Toluen } \\
\mathrm{e}\end{array}$ & 75 \\
\hline 14 & $f a c-\operatorname{Ir}(\mathrm{ppy})_{3}$ & 2 & THF & 56 \\
\hline
\end{tabular}

${ }^{a}$ Reaction conditions: trimethylphosphite $1 \mathrm{a}(0.3 \mathrm{mmol}, 3$ equiv), $\mathrm{N}-$ alkoxypyridinium tosylate $2 \mathrm{a}(0.1 \mathrm{mmol}, 1$ equiv), solvent $(1 \mathrm{~mL})$, blue LEDs (5W), 15 h. ${ }^{b}$ NMR yields are determined from ${ }^{31} \mathrm{P}$ NMR spectroscopy using tributyl phosphate as internal standard. $c$ trimethylphosphite 1 a $(0.1 \mathrm{mmol}, 1$ equiv), $N$-alkoxypyridinium tosylate $2 \mathbf{a}$ ( $0.1 \mathrm{mmol}, 1$ equiv). ${ }^{d}$ trimethylphosphite $1 \mathrm{a}(0.1 \mathrm{mmol}, 1$ equiv), $N$-alkoxypyridinium tosylate 2 a $(0.3 \mathrm{mmol}, 3$ equiv).

As depicted in Table 1, when 1a (3.0 equiv) was mixed with 2a (1.0 equiv) in acetonitrile in the presence of 5 mol\% of either Ru(bpy)3 (65\%, entry 1), Eosin Y (67 \%, entry 2) or Rose Bengal (63\%, entry 3) a good conversion of about $65 \%$ of the phosphate ester 3a was obtained in all cases. This conversion is raised up to $82 \%$ when the strong reductive $f a c-\operatorname{Ir}(\mathrm{ppy})_{3}$ was employed as a photocatalyst under the same conditions (entry 4), whereas only traces of 3a were detected in the absence of a photocatalyst (entry 5).

Having identified $f a c-\operatorname{Ir}(\mathrm{ppy})_{3}$ as a suitable catalyst for the reaction, we next investigated the stoichiometry of the reaction and showed that while the conversion of 3a drops to 72\% (entry 6) when equimolar amounts of $\mathbf{1 a}$ and $\mathbf{2 a}$ are used, $\mathbf{8 0 \%}$ of $\mathbf{3 a}$ is formed in excess of $\mathbf{2 a}$ ( 3 equivalents of $\mathbf{2 a}$ over one equivalent of 1a) (entry 7).

Interestingly, the photocatalyst loading can be decreased to $2 \mathrm{~mol} \%$ without affecting the efficiency of the reaction (81\%, entry 8). With this catalyst loading ( $2 \mathrm{~mol} \%$ ), a screening of solvent was performed (entries 914) and acetonitrile showed the best results. 

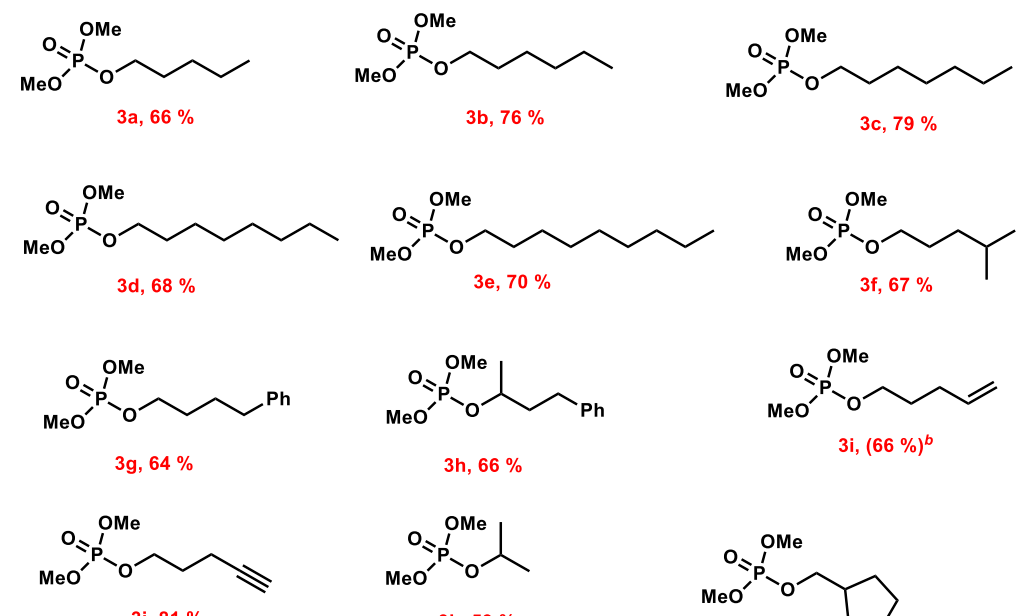

$$
\text { MeO'P-O OMe }
$$
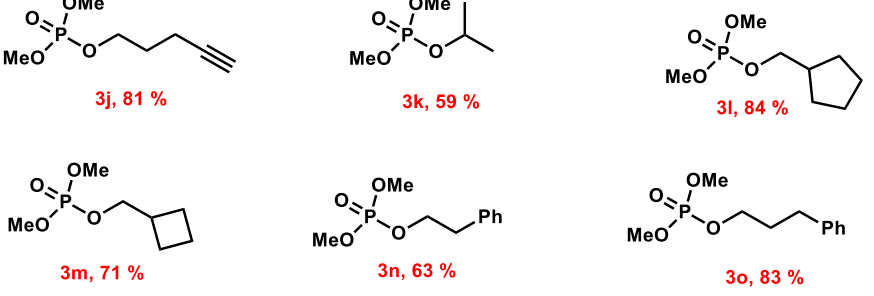<smiles>COP(=O)(OC)OCC1CCCCC1</smiles><smiles>COP(=O)(OC)OCCCCl</smiles><smiles>CCOP(=O)(OCC)OCCCc1ccccc1</smiles>

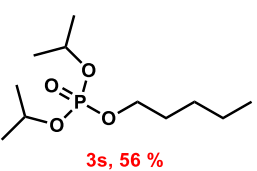<smiles>COP(=O)(OC)OC(C)CCCCn1c(=O)c2c(ncn2C)n(C)c1=O</smiles>

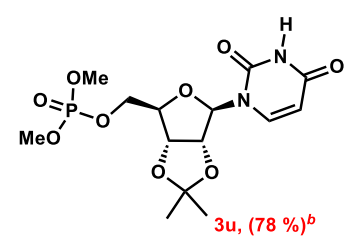

\section{Figure 1. Scope of the Photocatalytic Phosphate Synthesis. ${ }^{a}$}

${ }^{a}$ Reaction conditions: trimethylphosphite $\mathbf{1 a}\left(1.2 \mathrm{mmol}, 3\right.$ equiv), $N$-alkoxypyridinium tosylate $\mathbf{2 a}\left(0.4 \mathrm{mmol}, 1\right.$ equiv), fac-Ir(ppy) $_{3}(2$ mol\%), $\mathrm{CH}_{3} \mathrm{CN}\left(4 \mathrm{~mL}\right.$ ), blue LEDs (5W), $15 \mathrm{~h} .{ }^{b}$ Reaction conditions: trimethylphosphite 1a (4 mmol, 10 equiv), $N$-alkoxypyridinium tosylate $2 \mathbf{a}(0.4 \mathrm{mmol}, 1 \text { equiv), fac-Ir(ppy) })_{3}(2 \mathrm{~mol} \%), \mathrm{CH}_{3} \mathrm{CN}(4 \mathrm{~mL})$, blue LEDs (5W), $15 \mathrm{~h}$.

In order to explore the scope of the photoreaction, we first tested the reaction of trimethylphosphite 1a with various pyridinium salts under the optimized conditions. As shown in Figure 1 and in agreement with Bentrude's observations, ${ }^{11}$ radical addition of the alkoxy radicals to $\mathbf{1 a}$ is faster than the 1,5-hydrogen atom transfer and the phosphate esters 3a-3g have been obtained in good to excellent yields (64-79\%). ${ }^{12}$ It should be mentioned that no trace of the Minisci adduct, resulting from the radical addition of the alkyl radical, formed through radical translocation of the alkoxy radical, to the $N$-alkoypyridinium salt 2a (Supporting Information, page S6).

Interestingly, phosphate $\mathbf{3 h}$, resulting from initial addition of a secondary alkoxy radical with $\mathbf{1 a}$ and subsequent fragmentation was obtained in good $66 \%$ yield.

Equally important, phosphate esters bearing alkene and alkyne groups $\mathbf{3 i}$,j have also been isolated in good yields, 66 and $82 \%$, respectively. Here again, the oxygen radical attack is faster than the intramolecular cyclization. ${ }^{13}$ Additionally, eight phosphates $\mathbf{3 k - 3 q}$ derived from the reaction of ordinary oxygen-centered radicals and $\mathbf{1 a}$ have been isolated in good to excellent yields (59-88\%).

The reaction proceeds also with other phosphites such as triethyl-and triisopropyl-phosphites and the corresponding phosphate esters have been obtained in good yields ( 62 and 56\%, respectively).

To demonstrate the synthetic utility of the developed methodology, phosphonation of a naturally-relevant caffeine phosphate ester (3t) has been obtained in fair yields (61\%). Finally, our strategy is also amenable for the synthesis of 5'-phosphate nucleoside $3 \mathbf{u}$, which was obtained in good $78 \%$ yield.

To gain more insight about the reaction mechanism, we employed spin trapping/electron paramagnetic resonance (ST/EPR) experiments to characterize possible radicals formed during our photocatalytic reactions. ${ }^{14}$ In this context, we first combined the pyridinium salt $2 \mathbf{a}$ with the photocatalyst $\left(f a c^{-} \operatorname{Ir}(\mathrm{ppy})_{3}\right)$ in the presence of $N$-tert-Butyl- $\alpha$-phenylnitrone (PBN) as a spin trap in tert-butylbenzene under blue light irradiation. As depicted in Figure 2, a triplet of doublets because of the hyperfine couplings with the nitrogen nucleus $\left(\mathrm{a}_{\mathrm{N}}=14.3 \mathrm{G}\right)$ and 
with the proton in $\alpha$ position to the nitroxide nitrogen $\left(\mathrm{a}_{\mathrm{H}}=2.2 \mathrm{G}\right)$ was observed. Because these values are in good agreement with those reported by Dagousset et al. for the spin adduct (MeO-PBN), ${ }^{15}$ the structure of the detected radical could be assigned to $\mathbf{4 a - P B N}$, resulting from the addition of the alkoxy radical 4 a to PBN (Figure 2).

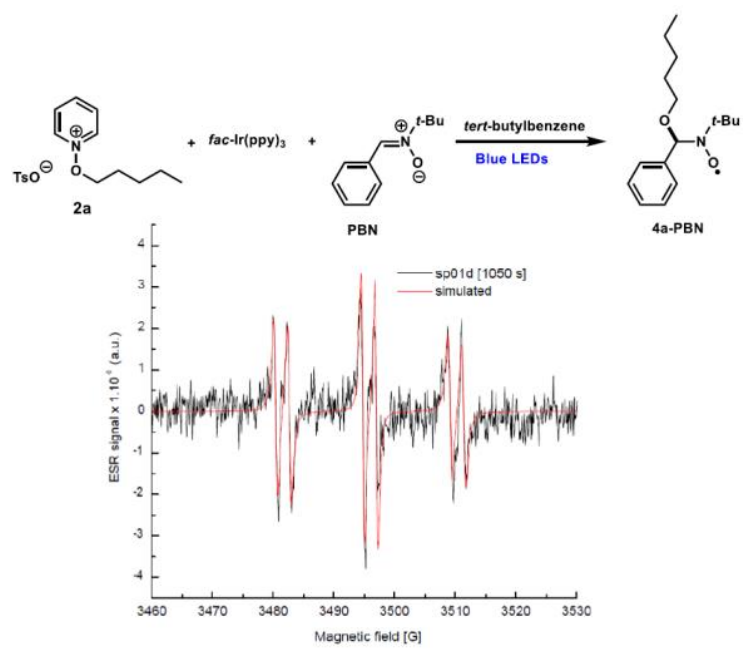

Figure 2. EPR spectrum of the reaction between pyridinium ion $2 \mathbf{a}$ in the presence of $f a c-\operatorname{Ir}(\mathrm{ppy})_{3}$ and the spin trap (PBN) in tert-butylbenzene under blue light irradiation $\left(\lambda_{\max }=420 \mathrm{~nm}\right)$.

The low reduction potential of $\mathbf{2 a}(-0.95 \mathrm{~V} / \mathrm{SCE})$ reported by Hong agrees with as a favorable reduction process. ${ }^{10}$ Phosphorus centered radicals are detected but the PBN (use for its light stability) cannot give more insight on the structure of the radical center due to its indirect spin trap character. Therefore, this radical can be tentatively proposed as $\mathbf{5}$ (Figure 3). Another proof of this mechanism is the release of methyl radical from the well-known fragmentation of tetra-coordinate phosphorus radical. The fact that the methyl radical is the only carbon radical observed indicates the selectivity of this process (path (a)) compared to the competitive process (path (b)) (Figure 3). This result was furthermore supported by ${ }^{31}$ P NMR spectroscopy of the photocatalytic reaction of 1a with $2 \mathbf{a}$, where the phosphate ester 3a was observed as a major product (85\%) and only $11 \%$ of 6 was detected in the crude mixture (Figure S5, Supporting Information, page S7).

To gather more mechanistic information, quantum yield of the reaction has been determined by actinometry and found to be 8.05 , which is indicative of a radical chain mechanism.

Taken together, a proposed reaction mechanism is depicted in Figure 3. It starts with the excitation of $f_{a c}-\operatorname{Ir}(\mathrm{ppy})_{3}$ with blue light to generate the highly reductive excited state $\left[\mathrm{fac}^{-} \operatorname{Ir}(\mathrm{ppy})_{3}\right]^{*}\left(\mathrm{E}_{0}{ }^{*}=-1.73\right)$ that can easily reduce the pyridinium ion (2) to form the alkoxy radical (4). Because reactions of the latter with phosphites (1) are diffusion-controlled, they form phosphoranyl radicals (5) prior to fragmentations. A subsequent fast $\beta$-scission leads to the formation of the phosphate ester (3). Alternatively, the phosphoranyl radical (5) can be oxidized either by $\left[\mathrm{fac}^{-} \operatorname{Ir}(\mathrm{ppy})_{3}\right]^{\bullet+}$ or the pyridinium salt (2) to form the phosphonium ion (7). Based on the quantum yield measurement, the second scenario is more likely. Finally, Arbuzov reaction between the pyridine, formed upon reduction of (2), and (7) leads to the formation of the desired phosphate ester (3) and $N$-methylpyridinium (9), which has been detected by NMR spectroscopy. 


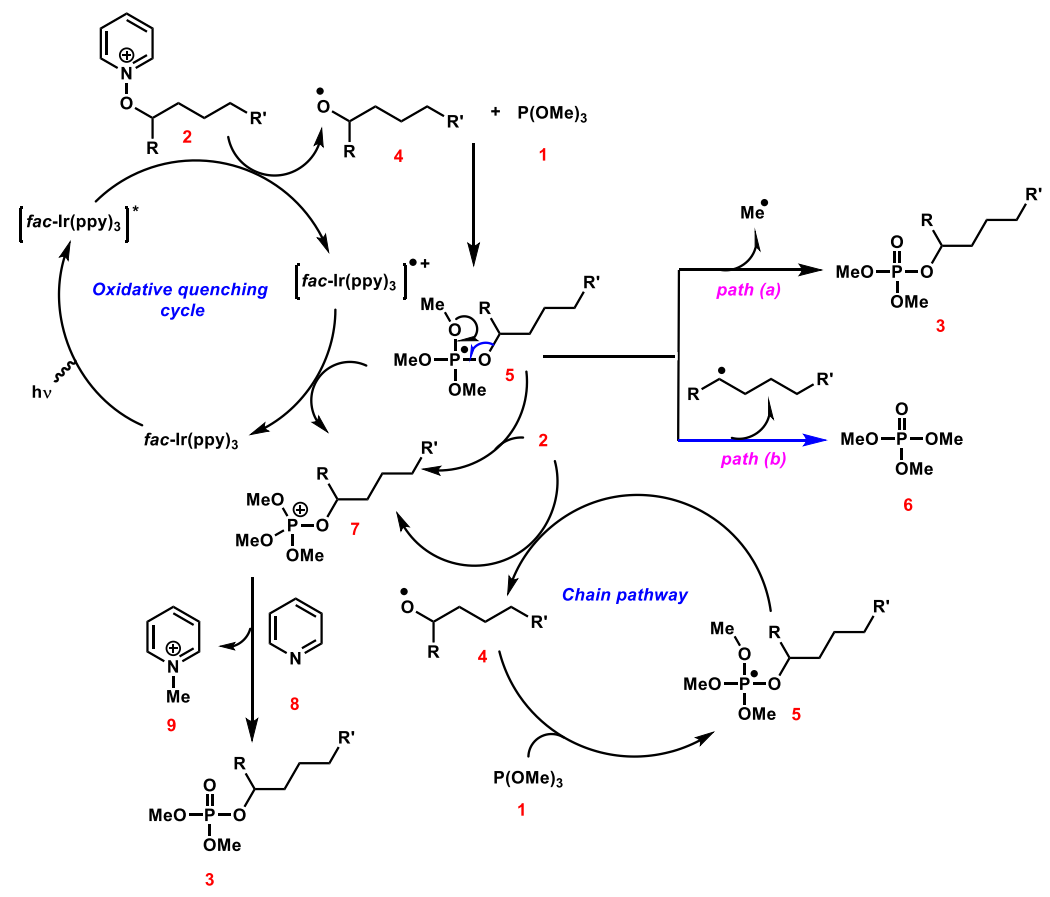

Figure 3. Proposed Mechanism for the Photocatalytic Synthesis of Phosphate Esters from the reaction of $N$-alkoxypyridinium ions with Phosphites.

This work demonstrates a new synthetic application of $N$-alkoxypyridinium ions as efficient generators of alkoxy radicals that can intercept with phosphites to lead to a facile access to phosphate esters. The scope is broad and can be applied in late stage phosphonation of complex structures. Interesting, mechanistic investigations, including EPR, NMR and quantum yield experiments allowed the suggestion of a reasonable reaction mechanism.

\section{ASSOCIATED CONTENT}

\section{Supporting Information}

The Supporting Information is available free of charge on the ACS Publications website.

Experimental procedures, full spectroscopic data, and copies of ${ }^{1} \mathrm{H}^{13} \mathrm{C}$ and ${ }^{31} \mathrm{P}$ NMR for all new compounds

\section{AUTHOR INFORMATION}

\section{Corresponding Author}

Sami Lakhdar-Normandie Univ., LCMT, ENSICAEN, UNICAEN, CNRS, 6, Boulevard Maréchal Juin, Caen 14000 France ; Université Paul Sabatier, Laboratoire Hétérochimie Fondamentale et Appliquée (LHFA, UMR 5069), 118 Route de Narbonne, 31062, Toulouse Cedex 09, France

lakhdar@chimie.ups-tlse.fr

\section{Authors}

Alya Inial-Normandie Univ., LCMT, ENSICAEN, UNICAEN, CNRS, 6, Boulevard Maréchal Juin, Caen 14000 France

Fabrice Morlet-Savary-Université de Haute-Alsace, CNRS, IS2M UMR 7361, F-68100 Mulhouse, France

Jacques Lalevée-Université de Haute-Alsace, CNRS, IS2M UMR 7361, F-68100 Mulhouse, France

Annie-Claude Gaumont-Normandie Univ., LCMT, ENSICAEN, UNICAEN, CNRS, 6, Boulevard Maréchal Juin, Caen 14000 France

\section{ACKNOWLEDGMENT}


The authors thank the CNRS, Normandie Université, Labex Synorg (ANR-11-LABX-0029) for financial support. We are grateful to Dr. Emmanuel Pfund for assistance with the preparation of the pyridinium salt (1u) and helpful discussion. I. thanks Region Normandie for a scholarship.

\section{DEDICATION}

Dedicated with respect and admiration to Prof. François Terrier.

\section{REFERENCES}

For selected examples, see: (1) (a) Sprecher, M.; Breslow, R.; Philosof-Oppenheimer, R.; Chavet, E. Steroid Phosphate Esters. Tetrahedron 1999, 55, 5465-5482. https://doi.org/10.1016/S0040-4020(99)00193-3. (b) Tang, W.; Zhang, X. New Chiral Phosphorus Ligands for Enantioselective Hydrogenation. Chem. Rev. 2003, 103, 3029-3069. https://doi.org/10.1021/cr020049i. (c) Paytan, A.; McLaughlin, K. The Oceanic Phosphorus Cycle. Chem. Rev. 2007, 107, 563-576. https://doi.org/10.1021/cr0503613. (d) Queffélec, C.; Petit, M.; Janvier, P.; Knight, D. A.; Bujoli, B. Surface Modification Using Phosphonic Acids and Esters. Chem. Rev. 2012, 112, 3777-3807. https://doi.org/10.1021/cr2004212.

(2) (a) Kosolapoff, G. M.; Maier, L. Organic Phosphorus Compounds; Wiley-Interscience: New York, 1972. (b) Hartley, F. R. The Chemistry of Organophosphorus Compounds; Wiley: New York, 1996. (c) Quin, L. D. A Guide to Organophosphorus Chemistry; Wiley: NewYork, 2000.

(3) Dhineshkumar, J.; Prabhu, K. R. Cross-Hetero-Dehydrogenative Coupling Reaction of Phosphites: A Catalytic MetalFree Phosphorylation of Amines and Alcohols. Org. Lett. 2013, 15, 6062-6065. https://doi.org/10.1021/ol402956b.

(4) Deng, L.; Wang, Y.; Mei, H.; Pan, Y.; Han, J. Electrochemical Dehydrogenative Phosphorylation of Alcohols for the Synthesis of Organophosphinates. J. Org. Chem. 2019, 84, 949-956. https://doi.org/10.1021/acs.joc.8b02882.

(5) Barton, D. H. R.; Bentley, T. J.; Hesse, R. H.; Mutterer, F.; Pechet, M. M. A Novel Synthesis of Phosphate Esters J. Chem. Soc. D, 1971, 912-914. https://doi.org/10.1039/C29710000912.

(6) For an excellent review, see: Bentrude, W. G. Phosphoranyl Radicals: Their Structure, Formation, and Reactions. Acc. Chem. Res. 1982, 15, 117-125. https://doi.org/10.1021/ar00076a004.

(7) For selected reviews, see: (a) Yoon, T. P.; Ischay, M. A.; Du, J. Visible Light Photocatalysis as a Greener Approach to Photochemical Synthesis. Nat. Chem. 2010, 2, 527-532. https://doi.org/10.1038/nchem.687. (b) Narayanam, J. M. R.; Stephenson, C. R. J. Visible Light Photoredox Catalysis: Applications in Organic Synthesis. Chem. Soc. Rev. 2011, 40, 102-113. https://doi.org/10.1039/b913880n. (c) Xuan, J.; Xiao, W.-J. Visible-Light Photoredox Catalysis. Angew. Chemie - Int. Ed. 2012, 51, 6828-6838. https://doi.org/10.1002/anie.201200223. (d) Prier, C. K.; Rankic, D. A.; MacMillan, D. W. C. Visible Light Photoredox Catalysis with Transition Metal Complexes: Applications in Organic Synthesis. Chem. Rev. 2013, 113, 5322-5363. https://doi.org/10.1021/cr300503r. (e) Romero, N. A.; Nicewicz, D. A. Organic Photoredox Catalysis. Chem. Rev. 2016, 116, 10075-10166. https://doi.org/10.1021/acs.chemrev.6b00057. (f) Wimmer, A.; König, B. Photocatalytic Formation of Carbon-Sulfur Bonds. Beilstein J. Org. Chem. 2018, 14, 54-83. https://doi.org/10.3762/bjoc.14.4. (g) Marzo, L.; Pagire, S. K.; Reiser, O.; König, B. Visible-Light Photocatalysis: Does It Make a Difference in Organic Synthesis? Angew. Chemie - Int. Ed. 2018, 57, 10034-10072. https://doi.org/10.1002/anie.201709766.

(8) For recent reviews, see: (a) Togni, A.; Rössler, S. L.; Jelier, B. J.; Magnier, E.; Dagousset, G.; Carreira, E. M. Pyridinium Salts as Redox-Active Functional Group Transfer Reagents. Angew. Chemie Int. Ed. 2019, 59, 2-19. https://doi.org/10.1002/anie.201911660. (b) He, F. S.; Ye, S.; Wu, J. Recent Advances in Pyridinium Salts as Radical Reservoirs in Organic Synthesis. ACS Catal. 2019, 9, 8943-8960. https://doi.org/10.1021/acscatal.9b03084

(9) (a) Murakami, M.; Ishida, N. $\beta$-Scission of Alkoxy Radicals in Synthetic Transformations. Chem. Lett. 2017, 46, 16921700. https://doi.org/10.1246/cl.170834. (b) Capaldo, L.; Ravelli, D. Alkoxy Radicals Generation: Facile Photocatalytic Reduction of: N -Alkoxyazinium or Azolium Salts. Chem. Commun. 2019, 55, 3029-3032. https://doi.org/10.1039/c9cc00035f.

(10) Kim, I.; Park, B.; Kang, G.; Kim, J.; Jung, H.; Lee, H.; Baik, M.-H.; Hong, S. Visible-Light-Induced Pyridylation of Remote $\mathrm{C}\left(\mathrm{sp}^{3}\right)-\mathrm{H}$ Bonds by Radical Translocation of N-Alkoxypyridinium Salts. Angew. Chemie - Int. Ed. 2018, 57, 1551715522. https://doi.org/10.1002/anie.201809879.

(11) Ding, B.; Bentrude, W. G. Trimethyl Phosphite as a Trap for Alkoxy Radicals Formed from the Ring Opening of Oxiranylcarbinyl Radicals. Conversion to Alkenes. Mechanistic Applications to the Study of C-C versus C-O Ring Cleavage. J. Am. Chem. Soc. 2003, 125, 3248-3259. https://doi.org/10.1021/ja020761x.

(12) While a very good conversion of 3a was observed by ${ }^{31}$ P NMR (Table 1, entry 8), 66\% of isolated yield was obtained. This yield drop has been reported by Yoshiki in the synthesis of structural related ester posphates: (e) Yoshiki, 0.; Tetuya, K.; Setsuo. Synthesis of Mixed Trialkyl Phosphates: Oxidative Phosphorylation of Alcohols with Dialkyl Phosphonates in the Presence of Copper(II) Chloride. Bull. Chem. Soc. Jpn. 1988, 61, 3359-3361. https://doi.org/10.1246/bcsj.61.3359.

(13) Kim, Y.; Lee, K.; Mathi, G. R.; Kim, I.; Hong, S. Visible-Light-Induced Cascade Radical Ring-Closure and Pyridylation for the Synthesis of Tetrahydrofurans. Green Chem. 2019, 21, 2082-2087. https://doi.org/10.1039/c9gc00414a.

(14) (a) Quint, V.; Morlet-Savary, F.; Lohier, J. F.; Lalevée, J.; Gaumont, A. C.; Lakhdar, S. Metal-Free, Visible LightPhotocatalyzed Synthesis of Benzo[b]Phosphole Oxides: Synthetic and Mechanistic Investigations. J. Am. Chem. Soc. 2016, 138, 7436-7441. https://doi.org/10.1021/jacs.6b04069. (b) Noël-Duchesneau, L.; Lagadic, E.; Morlet-Savary, F.; Lohier, J. F.; Chataigner, I.; Breugst, M.; Lalevée, J.; Gaumont, A. C.; Lakhdar, S. Metal-Free Synthesis of 6Phosphorylated Phenanthridines: Synthetic and Mechanistic Insights. Org. Lett. 2016, 18, 5900-5903. https://doi.org/10.1021/acs.orglett.6b02983. (c) Lecroq, W.; Bazille, P.; Morlet-Savary, F.; Breugst, M.; Lalevée, J.; Gaumont, A. C.; Lakhdar, S. Visible-Light-Mediated Metal-Free Synthesis of Aryl Phosphonates: Synthetic and 
Mechanistic Investigations. Org. Lett. 2018, 20, 4164-4167. https://doi.org/10.1021/acs.orglett.8b01379.

(a) Barthelemy, A.-L.; Tuccio, B.; Magnier, E.; Dagousset, G. Intermolecular Trapping of Alkoxyl Radicals with Alkenes: A New Route to Ether Synthesis. Synlett 2019, 30, 1489-1495. https://doi.org/10.1055/s-0037-1611785. (b) Barthelemy, A. L.; Tuccio, B.; Magnier, E.; Dagousset, G. Alkoxyl Radicals Generated under Photoredox Catalysis: A Strategy for Anti-Markovnikov Alkoxylation Reactions. Angew. Chemie - Int. Ed. 2018, 57 (42), 13790-13794. https://doi.org/10.1002/anie.201806522. 